\title{
THE DEVELOPMENT OF SYARI'AH COOPERATIVES INFORMATION SYSTEM MODEL
}

\author{
Ronny Malavia Mardani *) \\ Budi Wahono **)
}

\begin{abstract}
Indonesian Muslims have tremendous potential to be a pioneer and world Islamic economic center. Indonesia is the country with the largest Muslim population in the world. Indonesia has made policies that encourage the development of the Islamic finance industry. Classic problems that hinder the development of Cooperative Shari'ah Limited knowledge of cooperative management in financial management. Recognizing these circumstances, it would require a new technological innovation that the managers of cooperatives Shari'ah that some of those who do not understand how to manage the financial well be understood and easy to apply. Therefore, it is necessary to design the automated information system with the technology, so that businesses in the Cooperative Syari'ah able to easily prepare their own financial statements, without having to understand the concept of financial management. The purpose of this study is the description and design accountable models of Shari'ah cooperative information systems. The method used in this study is a qualitative method that is by arranging the Prototype Model. Results of design research model of this system, is able to develop a model of cooperative systems that facilitate cooperative Shari'ah management preparing financial reports quickly and accurately, can help managers and members of cooperatives Shari'ah to determine the growth koerasi quickly and can help managers to make decisions rapidly.
\end{abstract}

Keywords: Cooperative Shari'ah, Management Information Systems 


\section{PENDAHULUAN}

\subsection{Latar Belakang Masalah}

Saat ini kita menyadari bahwa sistem perekonomian barat ternyata tidak sesempurna dugaan kita sebelumnya. Krisis keuangan di Amerika Serikat pada tahun 2008 yang dipicu oleh sistem keuangan yang sangat mengandalkan riba mengakibatkan kebangkrutan perusahaan-perusahaan besar yang tidak pernah dibayangkan sebelumnya. Hingga kini dunia masih belum pulih dari dampak negatif krisis keuangan Amerika Serikat. Di eropa, krisis surat utang di Yunani telah merambat ke negara-negara Eropa lainnya. Hal ini semakin memperlihatkan bahwa ekonomi yang berbasis riba ternyata memiliki banyak kelemahan.

Berdasar kondisi pada perekonomian Amerika Serikat dan Negara-negara di eropa tersebut, dipandang perlu pendekatan-pendekatan pembangunan ekonomi yang baru. Pendekatan ekonomi Islam merupakan alternatif yang amat menjanjikan. Karena itu, tidaklah mengherankan bila kita melihat saat ini umat Islam di seluruh dunia tengah membangun fondasi ekonomi Syariah yang kuat.

Umat Islam Indonesia memiliki potensi yang amat besar untuk menjadi pelopor dan pusat ekonomi syariah dunia. Indonesia adalah negara dengan jumlah penduduk muslim terbesar di dunia. Indonesia sudah membuat kebijakan-kebijakan yang mendorong berkembangnya industri keuangan syariah. Hasilnya pun sangat menjanjikan. Hal ini bisa dilihat dari aset perbankan syariah secara keseluruhan (Bank Umum Syari'ah, dan Unit Usaha Syari'ah) selama 2011 mencatatkan pertumbuhan 49\% dengan total asset Rp149 triliun. Aset tersebut sekitar 4\% dari total aset perbankan nasional.

Mengingat aset industri keuangan syariah yang baru $4 \%$ dari aset perbankan nasional, ruang bagi industri keuangan syariah untuk berkembang masih terbuka lebar. Untuk itu, perlu dikembangkan sistem keuangan mikro yang baik, utamanya yang berbasiskan Islam. Sistem keuangan mikro yang baik, yang didukung oleh jumlah penduduk muslim yang besar, akan membuat Indonesia tumbuh menjadi pelopor di dunia dalam gerakan pemberantasan kemiskinan berbasis ajaran Islam. Kita harus memanfaatkan secara optimal potensi yang kita miliki ini.

Masalah klasik yang menghambat pengembangan Koperasi Syari'ah yaitu terbatasnya pengetahuan pengelola koperasi dalam pengelolaan keuangan berbasis syari'ah. Padahal kemampuan dalam pengelolaan keuangan dengan berbasis syari'ah akan memungkinkan manajemen memperoleh data dan informasi keuangan secara cepat, tepat dan sistematis. Fenomena yang terjadi adalah banyaknya Koperasi Syari'ah yang menghadapi kendala dalam 
hal permodalan, penyebabnya adalah terbatasnya investor yang bersedia untuk menanamkan modalnya pada Koperasi Syari'ah. Hal ini disebabkan ketidakmampuan Koperasi Syari'ah dalam menunjukkan bukti kinerja keuangan koperasi syari'ah dalam bentuk laporan keuangan.

\section{TINJAUAN TEORI}

\subsection{KOPERASI SYARI'AH}

Koperasi syari'ah secara teknis bisa dibilang sebagai koperasi yang prinsip kegiatan, tujuan dan kegiatan usahanya berdasarkan pada syariah Islam yaitu Al-Quran dan Assunnah. Pengertian umum dari Koperasi syari'ah adalah Koperasi syariah adalah badan usaha koperasi yang menjalankan usahanya dengan prinsip-prinsip syari'ah. Tujuan koperasi syari'ah adalah meningkatkan kesejahteraan anggota pada khususnya dan masyarakat pada umumnya serta turut membangun tatanan perekonomian yang berkeadilan sesuai dengan prinsip-prinsip islam.

\section{Produk jasa lembaga keuangan berbasis syariah}

a. Jasa untuk peminjam dana

- Mudharabah, adalah perjanjian antara penyedia modal dengan pengusaha. Setiap keuntungan yang diraih akan dibagi menurut rasio tertentu yang disepakati. Resiko kerugian ditanggung penuh oleh pihak Bank kecuali kerugian yang diakibatkan oleh kesalahan pengelolaan, kelalaian dan penyimpangan pihak nasabah seperti penyelewengan, kecurangan dan penyalahgunaan.

- Musyarakah (Joint Venture), konsep ini diterapkan pada model partnership atau joint venture. Keuntungan yang diraih akan dibagi dalam rasio yang disepakati sementara kerugian akan dibagi berdasarkan rasio ekuitas yang dimiliki masing-masing pihak.

- Murabahah, yakni penyaluran dana dalam bentuk jual beli. Bank akan membelikan barang yang dibutuhkan pengguna jasa kemudian menjualnya kembali ke pengguna jasa dengan harga yang dinaikkan sesuai margin keuntungan yang ditetapkan bank. Pengguna jasa dapat mengangsur barang tersebut.

- Takaful (asuransi islam)

b. Jasa untuk penyimpan dana

- Tabungan mudharabah

- Wadi'ah (jasa penitipan), adalah jasa penitipan dana dimana penitip dapat mengambil dana tersebut sewaktu-waktu. 
- Deposito Mudharabah, nasabah menyimpan dana di Bank dalam kurun waktu yang tertentu. Keuntungan dari investasi dana nasabah dilakukan dengan nisbah bagi hasil tertentu antara bank dan nasabah.

\subsection{SISTEM INFORMASI}

Menurut Laitch dan Bavis menjelaskan bahwa sistem informasi adalah suatu sistem di dalam sebuah organisasi yang mempertemukan kebutuhan pengolahan transaksi harian, mendukung operasi, bersifat manajerial dan kegiatan strategi dari suatu organisasi dan menyediakan pihak luar tertentudengan laporan-laporan yang diperlukan (Laitch, 2007:8). Menggunakan pendekatan sistem untuk mengembangkan solusi sistem informasi dapat dipandang sebagai proses multilangkah yang disebut siklus pengembangan sistem informasi (information systems development cycle), yang juga dikenal sebagai siklus hidup pengembangan sistem (systems development life cycle-SDLC) yang mencakup langkahlangkah:

a. Tahap pertama: Kenali masalah/kesempatan

1) Investigasi sistem

Dalam tahap ini perlu dikenali permasalahan yang terjadi

b. Tahap Kedua: Kembangkan solusi Sistem informasi

2) Analisis sistem

a) Analisis kebutuhan informasi dari user, lingkungan organisasi dan sistem-sistem lain yang sedang berjalan.

b) Analisis aktivitas, sumber daya, dan produk system yang sedang berjalan.

c) Susun kebutuhan fungsional dari satu sistem yang mampu memenuhi kebutuhan user, yaitu : Kebutuhan akan user interface, Kebutuhan pengolahan, Kebutuhan storage dan Kebutuhan akan control

3) Desain sistem

a) Buat spesifikasi perangkat keras, piranti lunak, tenaga manusia, jaringan dan sumber daya data, serta produk-produk informasi yang dapat memenuhi kebutuhan fungsional dari sistem yang diusulkan. 


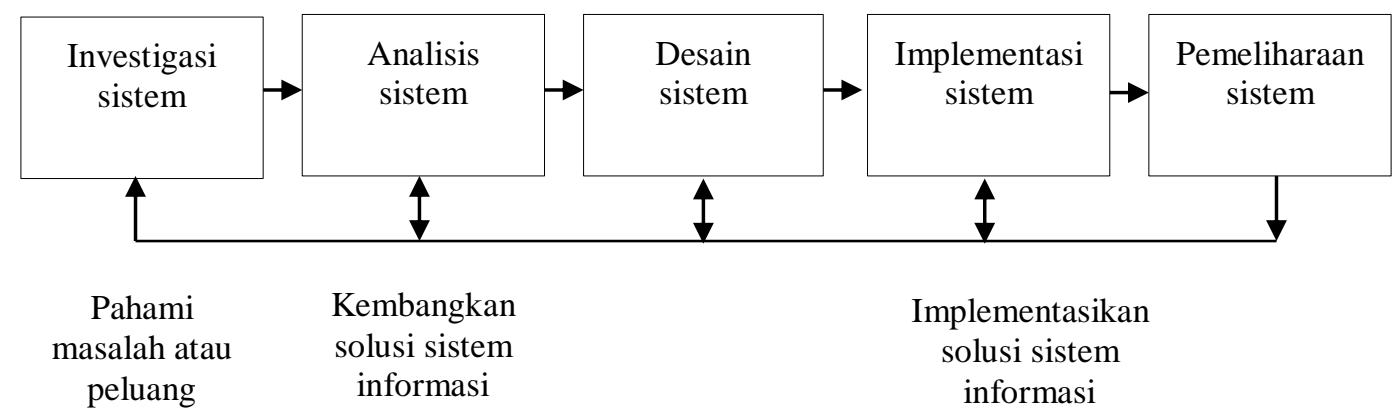

Gambar 1. Siklus pengembangan sistem informasi

b) Aktivitas yang dilakukan : a) Desain 'user interface': layer, formulir, dan dialog; b) Desain data: entity/object, atribut, relationship, kaidah integritas, dll dan c) Desain proses: user services, application services, dan data services.

c) Desain output sistem antara lain : a) Spesifikasi 'user interface'; b) pesifikasi basisdata; c) Spesifikasi piranti lunak; d) Spesifikasi perangkat keras dan jaringan;

e) Spesifikasi personil

c. Tahap ketiga: Terapkan solusi sistem informasi:

4) Implementasi sistem

Aktivitas dalam tahap ini adalah pengadaan perangkat keras dan piranti lunak, Uji sistem dan pelatihan pengguna, pengoperasian dan penggunanya serta Konversi ke sistem baru

5) Perawatan sistem

Lakukan proses review pasca implementasi untuk memantau, mengevaluasi dan memodifikasi sistem sesuai kebutuhan.

Dalam melakukan pemodelan sistem menggunakan Flowchart dan Data Flow Diagram (DFD). Flowchart adalah bagan (chart) yang menunjukan aliran (flow) didalam program atau prosedur sistem secara logika, digunakan terutama sebagai alat bantu komunikasi dan dokumentasi. Ada 5 macam flowchart, yaitu : flowchart sistem, flowchart dokumen, flowchart skematik, flowchart program dan flowchart proses.(Kusrini,2007:80).

\section{METODE PENELITIAN}

\subsection{Desain Penelitian}

Dalam penelitian ini, design penelitian yang digunakan dimulai dengan melakukan pendeskripsian alur setiap transaksi dalam koperasi syari'ah. Dari pendeskripsian ini 
kemudian diikuti perancangan sistem informasi koperasi syari'ah berbasis teknologi yang dapat membantu pengelola koperasi syari'ah untuk menghasilkan laporan keuangan yang akuntabel. Berdasarkan hasil perancangan (perencanaan) sistem dilanjutkan dengan desain sistem. Selanjutnya adalah uji coba dan sistem evaluasi dilakukan setelah tahap desain sistem selesai dilakukan.

Proses penelitian tersebut merujuk pada pendapat Susman (1983) dengan mengembangkan model sebagai berikut: 1) diagnosis problematika (identifikasi dan kodifikasi masalah), 2) rencana, tindakan, 3) pelaksanaan (pendampingan), 4) penyusunan indikator keberhasilan (pelatihan), 5) monitoring dan evaluasi, yang kesemua proses ini digunakan untuk mencapai target yang sudah digariskan.

\subsection{Lokasi Penelitian}

Penelitian ini dilakukan di kota Malang Jawa Timur, dengan mengambil obyek penelitian pelaku bisnis koperasi syari'ah. Hal ini disebabkan tumbuh pesatnya koperasi yang menerapkan sistem syari'ah di Kota Malang.

\subsection{Sumber dan Jenis Data}

Sumber data adalah subyek dimana data dapat diperoleh. Subyek dalam penelitian ini berjumlah dua pihak, diantaranya: (1) pengurus koperasi syari'ah; (2) karyawan bagian administrasi dan keuangan.

Jenis data yang digunakan dalam penelitian ini, terdiri dari 2 sumber yaitu: data primer (sumber data utama) adalah data yang diperoleh langsung dari sumbernya (subyek penelitian), diamati dan dicatat, yang untuk pertama kalinya dilakukan melalui observasi (pengamatan) dan wawancara. Data skunder yaitu data yang tidak dilakukan secara langsung oleh peneliti, seperti buku, majalah ilmiah, arsip, dokumentasi pribadi dan resmi dan sebagainya.

\subsection{Teknik Pengumpulan Data}

Adapun cara untuk mengumpulkan data, dilakukan dengan teknik sebagai berikut: pertama, untuk kategori data primer, peneliti melakukannya dengan cara wawancara atau melakukan tanya jawab secara langsung dengan responden/narasumber yang ada di lokasi penelitian seperti melakukan wawancara dengan pengurus dan karyawan koperasi, 
melakukan observasi atau pengamatan terhadap obyek, dan dokumentasi (mengumpulkan data dengan cara mencari dan mengumpulkan melalui dokumen yang berhasil ditemukan), kedua, dokumentasi, yakni mempelajari atau menelaah dokumen seperti transaksi yang terjadi seperti simpan pinjam, setoran dan penarikan tabungan, setoran dan penarikan deposito dan pencatatan akuntansi. Sedangkan untuk kategori data sekunder (library research), peneliti melakukannya dengan mencari data dari: 1). Bahan primer, yang terdiri dari data usaha koperasi syari'ah. 2). Bahan sekunder, yang terdiri dari hasil-hasil penelitian, hasil karya ilmiah. 3) Bahan tersier, yaitu bahan-bahan yang memberikan informasi tentang bahan hukum primer dan bahan sekunder, seperti: landasan dan prinsip-prinsip jasa keuangan syari'ah, aturan pemerintah mengenai jasa keuangan, dan sebagainya.

\subsection{Analisis Data}

Analisis data merupakan bagian dalam melakukan penelitian. Dalam penelitian kualitatif, analisis data yang telah ditemui sejak pertama peneliti datang ke lokasi penelitian, yang dilaksanakan secara intensif sejak awal pengumpulan data lapangan sampai akhir data terkumpul semua. Berdasarkan uraian di atas, maka prosedur analisis data yang digunakan dalam penelitian ini sebagai berikut:

1) Reduksi Data

Reduksi data termasuk dalam kategori pekerjaan analisis data. Data yang berupa catatan lapangan (field notes) sebagai bahan mentah, dirangkum, di ikhtisarkan atau diseleksi.

2) Displai Data

Hasil reduksi perlu "didisplai" secara tertentu untuk masing-masing problem dan dimengerti duduk persoalanya. Displai data dapat membantu peneliti untuk melihat gambaran keseluruhan atau bagian-bagian tertentu dari hasil penelitian.

3) Mengambil Kesimpulan

Muara dari kesimpulan kegiatan analisis data kualitatif terletak pada deskripsi atau penuturan tentang apa yang dihasilkan, dapat dimengerti berkenaan dengan suatu problem yang diteliti. Dari sinilah lahir kesimpulan atau permasalahan yang bobotnya tergolong komprehensif dan mendalam (deepth).

Setalah data dianalisis, tahap selanjutnya adalah perancangan dan desain sistem. Metode pendekatan dan pengembangan sistem yang digunakan akan dikemukakan secara rinci sebagai berikut : 
a. Metode Pendekatan Sistem

Metode Pendekatan sistem yang digunakan pada penelitian ini menggunakan metode terstuktur yaitu suatu proses untuk mengimplementasikan urutan langkah untuk menyelesaikan suatu masalah dalam bentuk program. Pemrograman Terstruktur adalah suatu proses mengimplementasikan urutan langkah untuk menyelesaikan suatu masalah dalam bentuk program.

b. Metode Pengembangan Sistem

Pengembangan sistem (systems development) dapat berarti menyusun suatu sistem yang baru untuk menggantikan sistem yang lama secara keseluruhan atau memperbaiki sistem yang ada. Guna pencapaian tujuan dalam perancangan perangkat lunak Sistem Informasi Koperasi Syari'ah Berbasis Teknologi Informasi, digunakan metode siklus hidup pengembangan perangkat lunak berupa Prototype Model. Prototype model ini merupakan metode siklus hidup pengembangan perangkat lunak yang bertujuan mendapatkan kebutuhan yang jelas. Adapun tahapan proses yang akan dilakukan adalah sebagai berikut : Dokumentasi kebutuhan, membuat prototype dari kebutuhan tersebut, Uji coba dan Evaluasi terhadap prototype, dan membuat perangkat lunak akhir.

Dalam tahapan di atas, yang merupakan tahapan berupa prototype adalah tahapan nomor satu, kedua dan ketiga. Pada ketiga tahapan tersebutlah akan terjadi siklus pengembangan perangkat lunak hingga hal-hal utama pada perangkat lunak tersebut selesai dibuat.

\section{HASIL PENELITIAN}

\subsection{Hasil Penelitian}

Berdasarkan data dari Web Dinas Koperasi dan UMKM Kota Malang (http://dinkop.malangkota.go.id), kuisioner disebarkan pada 46 koperasi syari'ah di wilayah kota Malang. Dari 46 kuisioner yang disebarkan, kuisioner diterima kembali sebanyak 29 kuisioner. Berdasarkan hasil penyebaran kuisioner, dapat diketahui bahwa dari 29 koperasi syari'ah yang ada, secara keseluruhan (100\%) menawarkan produk tabungan mudharabah, $59 \%$ menawarkan produk tabungan haji, 48\% menawarkan tabungan qurban, $100 \%$ menawarkan produk deposito, pembiayaan musyarakah, pembiayaan murabahah, pembiayaan mudharabah, 7\% menawarkan pembiayaan qordhul hasan, dan hanya 7\% yang menggunakan sistem berbasis teknologi informasi. 
Berdasarkan uraian diatas, tampak bahwa produk yang ditawarkan oleh koperasi syari'ah antara lain : tabungan mudharabah, tabungan haji, tabungan qurban, deposito, pembiayaan musyarakah, pembiayaan murabahah, pembiayaan mudharabah, dan pembiayaan qordhul hasan. Maka pengembangan sistem koperasi syari'ah diutamakan dengan menyediakan fasilitas terkait produk tersebut.

\subsection{Kelemahan Sistem yang Sedang Berjalan}

Berdasarkan hasil analisis terhadap sistem yang berjalan. Beberapa kelemahan dari sistem berjalan antara lain: 1) Seluruh aktivitas koperasi masih dikerjakan secara manual, meskipun beberapa sudah menggunakan MS Excel; 2) Pengurus sulit menyusun laporan keuangan koperasi secara cepat dan akurat; 3) Manajer sulit untuk mengambil keputusan secara cepat.

Berdasarkan hasil analasis awal tersebut dan tujuan penelitian ini dilakukan, maka perlu dilakukan perancangan model sistem informasi koperasi syari'ah yang akuntabel dan berbasis teknologi informasi. Perancangan sistem informasi koperasi syari'ah ini dapat memberikan manfaat sebagai berikut: 1) Pengurus koperasi syari'ah dapat melakukan transaksi secara efektif; 2) Pengurus dapat menyusun laporan keuangan secara cepat dan akurat; 3) Pengurus memiliki data anggota yang akurat; 4) Manajer dapat mengetahui kondisi keuangan secara cepat; 5) Manajer dapat mengambil keputusan secara cepat; 6) Meningkatkan pelayanan kepada anggota koperasi; 6) Meningkatkan kepercayaan anggota kepada koperasi

\subsection{Perancangan Sistem}

\subsubsection{Pengguna Sistem}

Sistem koperasi syari'ah ini didesain dengan 4 jenis pengguna (user) antara lain : Administrator (Manajer/Wakil Manajer), Bagian Tabungan, Simpanan dan Deposito, Bagian Pembiayaan, dan Bagian Accounting. Administrator dapat mengakses semua modul atau menu yang tersedia pada sistem dan yang terpenting adalah menginput semua produk tabungan, deposito, pembiayaan serta menentukan hak akses bagi seluruh pengguna sistem. Bagian tabungan, simpanan dan deposito dapat mengakses seluruh modul yang berhubungan dengan tabungan, simpanan dan deposito. Bagian pembiayaan dapat mengakses seluruh modul yang berhubungan dengan pembiayaan. Bagian accounting dapat mengakses seluruh modul yang berhubungan dengan accounting. 
Selanjutnya, pada tahapan perancangan sistem ini kegiatan yang dilakukan meliputi perancangan proses penggunaan sistem koperasi syari'ah melalui diagram aktivitas, perancangan database, perancangan input dan output, dan perancangan tampilan user interface (GUI).

\subsubsection{Diagram Aktivitas}

Diagram aktivitas merupakan gambaran melalui flowchart setiap aktivitas dalam sistem informasi koperasi syari'ah. Dalam rancangan sistem koperasi syari'ah ini terdapat 38 diagram aktivitas. Berikut disajikan 7 diagram aktivitas utama yang dapat dirangkum dalam tabel 1 sebagai berikut :

Tabel 1. Diagram Aktivitas

\begin{tabular}{|c|c|c|c|}
\hline No & Nama Aktivitas & Diagram & Keterangan \\
\hline 1 & Login & & $\begin{array}{l}\text { Aktivitas ini merupakan langkah pertama } \\
\text { untuk dapat masuk pada system koperasi } \\
\text { syari'ah yang dimulai dengan menginput } \\
\text { username dan password, selanjutnya } \\
\text { meng-klik tombol Login }\end{array}$ \\
\hline 2 & $\begin{array}{l}\text { Diagram Aktivitas } \\
\text { Setup Nomor } \\
\text { Perkiraan } \\
\text { Akuntansi }\end{array}$ & $\frac{5}{5-}$ & $\begin{array}{l}\text { Setup nomor perkiraan akuntansi hanya } \\
\text { bisa dilakukan oleh bagian akuntansi. } \\
\text { Aktivitas ini diperlukan untuk } \\
\text { mensetting nomor perkiraan akuntansi } \\
\text { untuk keperluan penyusunan laporan } \\
\text { keuangan }\end{array}$ \\
\hline 3 & $\begin{array}{l}\text { Diagram Aktivitas } \\
\text { Pendaftaran } \\
\text { Anggota }\end{array}$ & 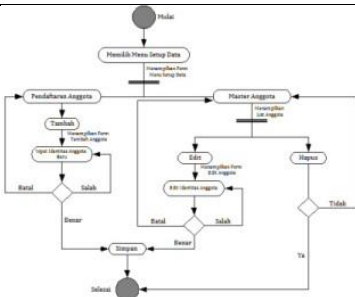 & $\begin{array}{l}\text { Pendaftaran Anggota hanya bisa } \\
\text { dilakukan oleh administrator (admin). } \\
\text { Aktivitas ini dilakukan untuk mendaftar } \\
\text { orang yang akan menjadi anggota } \\
\text { koperasi. }\end{array}$ \\
\hline 4 & $\begin{array}{l}\text { Diagram Aktivitas } \\
\text { Pembukaan } \\
\text { Tabungan }\end{array}$ & 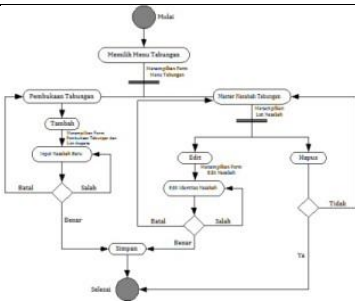 & $\begin{array}{l}\text { Pembukaan Tabungan hanya bisa } \\
\text { dilakukan oleh Admin Tabungan. } \\
\text { Aktivitas ini dilakukan saat ada anggota } \\
\text { koperasi syari'ah yang akan membuka } \\
\text { tabungan }\end{array}$ \\
\hline
\end{tabular}




\begin{tabular}{|l|l|c|l|}
\hline No & Nama Aktivitas & \multicolumn{2}{|c|}{ Keterangan } \\
\hline 5 & $\begin{array}{l}\text { Diagram Aktivitas } \\
\text { Pembukaan } \\
\text { Deposito }\end{array}$ & $\begin{array}{l}\text { Pembukaan Deposito hanya bisa } \\
\text { dilakukan oleh Admin Deposito. } \\
\text { Aktivitas ini dilakukan saat ada anggota } \\
\text { koperasi syari'ah yang akan membuka } \\
\text { Deposito } \\
\text { Pembukaan } \\
\text { Pembiayaan }\end{array}$ & $\begin{array}{l}\text { Pembukaan Pembiayaan hanya bisa } \\
\text { dilakukan oleh Admin Pembiayan. } \\
\text { Aktivitas ini dilakukan saat ada anggota } \\
\text { koperasi syari'ah yang akan mengajukan } \\
\text { pembiayaan. }\end{array}$ \\
\hline $\begin{array}{l}\text { Diagram Aktivitas } \\
\text { Jurnal Umum }\end{array}$ & $\begin{array}{l}\text { Jurnal umum hanya bisa dilakukan oleh } \\
\text { bagian accounting. Aktivitas ini } \\
\text { dilakukan saat diperlukan input jurnal } \\
\text { transaksi oleh bagian accounting }\end{array}$ \\
\hline
\end{tabular}

\subsubsection{Perancangan Input/Output Sistem Informasi Koperasi Syari’ah}

\section{a. Perancangan Form}

Perancangan form merupakan rencana desain bentuk input pada sistem yang dibagi menjadi 4 bagian yaitu form input untuk Administrator, Bagian Tabungan, Simpanan dan Deposito, Bagian Pembiayaan dan Bagian Accounting. Berikut diuraikan daftar perancangan form tersebut.

1. Administrator (Manajer/Wakil Manajer)

Form input yang disediakan untuk administrator (Manajer/Wakil Manajer) terdiri dari 13 Form yaitu Form Input Pendaftaran Anggota, Produk Tabungan, Produk Deposito, Produk Pembiayaan, Produk Simpanan, Sifat Pembiayaan, Form Penggunaan Pembiayaan, Golongan Debitur Pembiayaan, Area, Pekerjaan, Sektor Ekonomi, Account Officer dan Otorisasi Staff. Berikut disajikan 2 contoh form input sebagaimana diuraikan diatas : 


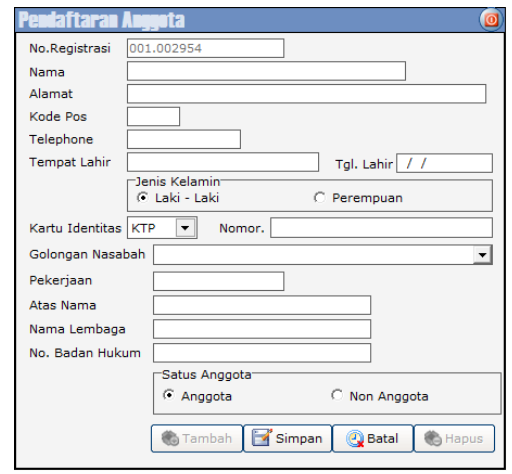

Gambar 1 Form Input Pendaftaran Anggota

2. Bagian Tabungan, Simpanan dan Deposito

Form input yang disediakan untuk Bagian Tabungan, Simpanan dan Deposito terdiri dari 4 Form yaitu Form Input Pembukaan Tabungan, Form Input Transaksi Tabungan, Form Input Pembukaan Deposito, dan Form Input Transaksi Deposito. Berikut disajikan contoh form input sebagaimana disebutkan sebelumnya :

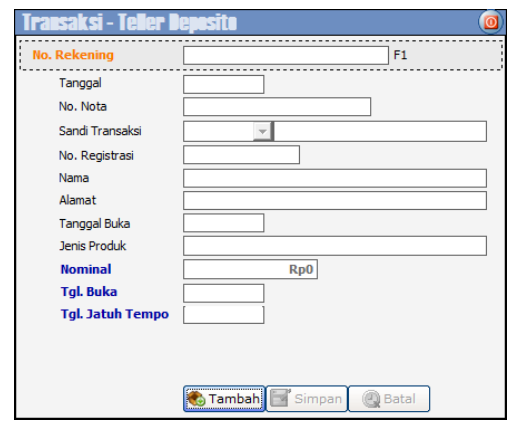

Gambar 2 Form Input Transaksi Deposito

3. Bagian Pembiayaan

Form input yang disediakan untuk Bagian Pembiayaan terdiri dari 3 Form yaitu Form Input Pembukaan Pembiayaan, Form Input Transaksi Pembiayaan dan Form Input Simulasi Pembiayaan. Berikut disajikan 2 contoh form input sebagaimana diuraikan diatas :

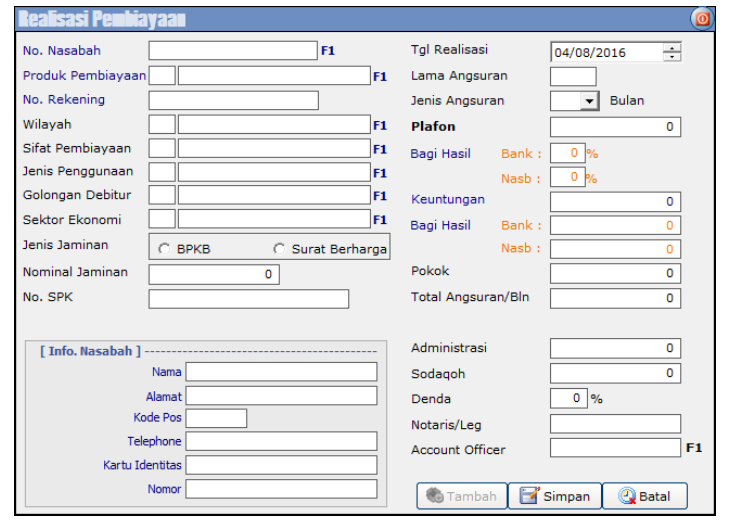

Gambar 3 Form Input Pembukaan Pembiayaan 


\section{Bagian Accounting}

Form input yang disediakan untuk Bagian Accounting terdiri dari 4 Form yaitu Form Input Nomor Perkiraan Akuntansi, Form Input Jurnal Umum, Form Input Proses Posting dan Form Input Proses Akhir Bulan. Berikut disajikan 2 contoh form input sebagaimana diuraikan diatas :

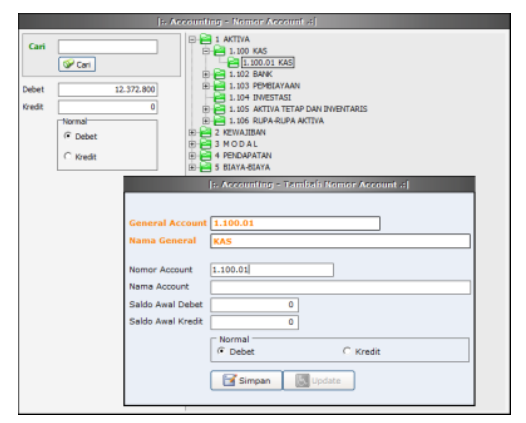

Gambar 4 Form Input Nomor Perkiraan Akuntansi

\section{b. Perancangan Laporan}

Perancangan laporan merupakan perancangan bentuk output yang dibagi menjadi 4 bagian yaitu laporan untuk Administrator, Bagian Tabungan, Simpanan dan Deposito, Bagian Pembiayaan dan Bagian Accounting. Berikut ini adalah daftar perancangan laporan tersebut.

1. Administrator (Manajer/Wakil Manajer)

Desain laporan yang disediakan untuk Administrator (Manajer/Wakil Manajer) terdiri dari 1 laporan yaitu laporan daftar anggota.

2. Bagian Tabungan, Simpanan dan Deposito

Desain laporan yang disediakan untuk Bagian Tabungan, Simpanan dan Deposito terdiri dari 6 laporan yaitu Laporan Mutasi Harian Tabungan, Laporan Bagi Hasil Tabungan, Laporan Nominatif Tabungan, Laporan Mutasi Harian Deposito, Laporan Deposito Jatuh Tempo, dan Laporan Nominatif Deposito.

3. Bagian Pembiayaan

Desain laporan yang disediakan untuk Bagian Pembiayaan terdiri dari 4 laporan yaitu Laporan Mutasi Harian Pembiayaan, Laporan Angsuran Nasabah, Laporan Nominatif Pembiayaan, dan Laporan Daftar Tagihan.

4. Bagian Accounting

Desain laporan yang disediakan untuk Bagian Accounting terdiri dari 6 laporan yaitu Laporan Jurnal Mutasi Transaksi, Laporan Buku Besar, Laporan Neraca Saldo, Laporan Laba Rugi, Laporan Neraca dan Laporan Distribusi pendapatan. 
Jurnal Ilmiah Bidang Manajemen dan Akuntansi (JEMA)

Vol. 14 No. 1 (2017) - http://riset.unisma.ac.id/index.php/jema

\section{c. Perancangan Database Sistem Informasi Koperasi Syari’ah}

Tahap selanjutnya adalah merancang kebutuhan database. Database pada sistem ini didesain terdiri dari 18 tabel, antara lain : Tabel Master Nasabah, Tabel Master Golongan Nasabah, Tabel Master Pengguna, Tabel Master Produk Syariah, Tabel Jadwal Bagi Hasil, Tabel Master Tabungan, Tabel Mutasi Tabungan, Tabel Master Deposito, Tabel Mutasi Deposito, Tabel Master Pembiayaan, Tabel Mutasi Pembiayaan, Tabel Jadwal Angsuran, Tabel Realisasi Angsuran, Tabel Master Simpanan, Tabel Mutasi Simpanan, Tabel Accounting, Tabel Head Jurnal Transaksi, Tabel Nomor Perkiraan Akuntansi dan Tabel Detail Jurnal Transaksi. Berikut disajikan gambar relasi antar tabel dalam database koperasi syari'ah:

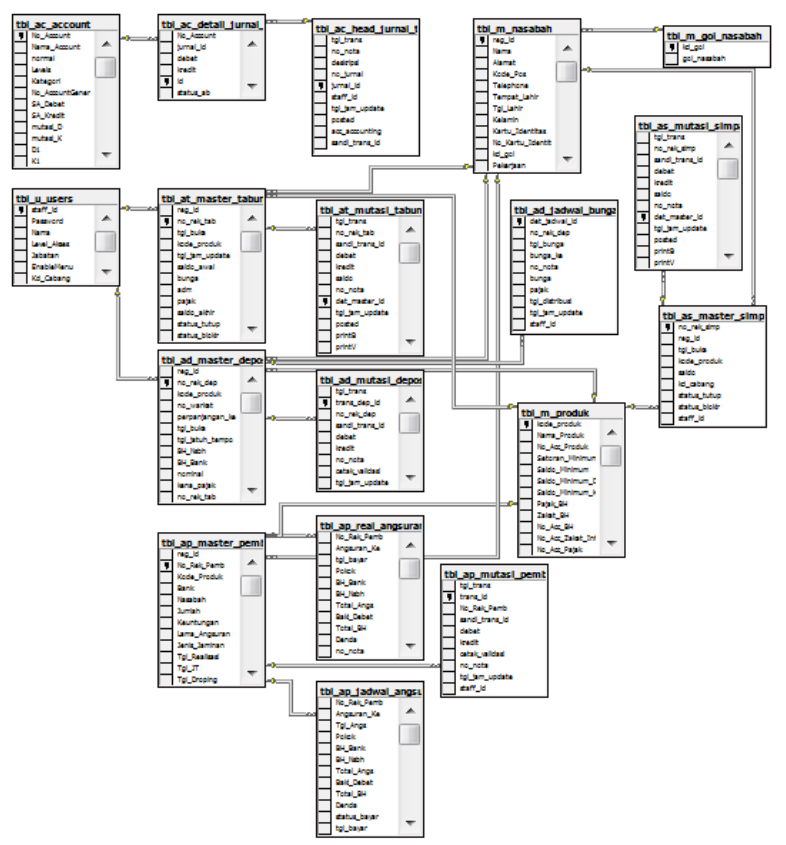

Gambar 16 Tabel Relation Sistem Koperasi Syari'ah

\section{Kebutuhan Perangkat Keras (Hardware)}

Perangkat keras yang mendukung sistem ini adalah sebuah unit komputer dengan spesifikasi minimal sebagai berikut:

1. Server:

Spesifikasi server yang dibutuhkan dalam sistem ini adalah : Processor Minimal Intel Pentium IV, Memory Minimal 2 GB, Harddisk Minimal 300 GB dan Ethernet 100 Mbps upgrade to $1000 \mathrm{Mbps}$

2. Client:

Spesifikasi client yang dibutuhkan dalam sistem ini adalah Processor : Setara dengan Intel Pentium IV atau keatas, Memory Minimal 2 MB, Harddisk minimal 80 GB dan Network Interface Card Transmisi Data 10/100/1000 Mbps 
Jurnal IImiah Bidang Manajemen dan Akuntansi (JEMA)

Vol. 14 No. 1 (2017) - http://riset.unisma.ac.id/index.php/jema

3. Switch Hub 10/100/1000 Mbps

\section{Kebutuhan Perangkat Lunak (Software)}

Spesifikasi sistem operasi dan perangkat lunak yang mendukung adalah sebagai berikut:

1. Server:

a. Sistem Operasi Windows Server 2008

b. Database software: SQL Server 2000

2. Client:

a. Microsoft Windows XP Professional Version 2002 Service Pack 2

b. Pdf Creator

c. Microsoft Office 2010

\section{KESIMPULAN DAN SARAN}

\subsection{Simpulan}

Berdasarkan uraian dan pembahasan pada bab-bab sebelumnya, maka dapat ditarik simpulan sebagai berikut:

1. Perancangan model sistem Pengembangan Model Sistem Informasi Koperasi Syari'ah Berbasis Teknologi Informasi dapat mempermudah pegurus koperasi menyusun laporan keuangan secara cepat dan akurat

2. Model sistem Pengembangan Model Sistem Informasi Koperasi Syari'ah Berbasis Teknologi Informasi ini dapat membantu manajer dan anggota koperasi syari'ah untuk mengetahui pertumbuhan koerasi dengan cepat.

3. Model Sistem Informasi Koperasi Syari'ah Berbasis Teknologi Informasi ini dapat membantu manajer untuk mengambil keputusan secara cepat.

4. Model sistem Pengembangan Model Sistem Informasi Koperasi Syari'ah Berbasis Teknologi Informasi ini dapat mambnatu pengurus koperasi untuk memberikan pelayanan terbaik kepada anggotanya

\subsection{Saran}

Sistem yang dibangun masih memiliki beberapa kekurangan serta keterbatasan, maka dari itu ada beberapa hal yang perlu dikembangkan dari sistem tersebut agar menjadi lebih baik untuk selanjutnya, antara lain: 1) Menggunakan barcode untuk input transaksi, 2) Menggunakan printer khusus cetak tabungan, agar hasil cetak dapat lebih baik, 3) Menggunakan jaringan wireless untuk setiap client dan 4) Penambahan aplikasi cetak kartu anggota yang terintegrasi dengan barcode 


\section{DAFTAR PUSTAKA}

Al Fatta, Hanif. 2007. Analisis dan Perancangan Sistem Informasi; untuk Keunggulan Bersaing Perusahaan \& Organisasi Modern. Yogyakarta : ANDI.

Hafiarni, Fanny. (2009). Mudah Membuat Laporan Keuangan dengan Microsoft Excel. Cetakan pertama. Jakarta: Tangga Pustaka

Hayashi, M. (2002). The Role of Subcontracting in SME development in Indonesia: Microlevel Evidence From the Metal Working and Machinery Industry. Journal of Asian Economics. v.13. pp. 1-26.

Hendrojogi, Msc. 1997. Koperasi: Azas-Azas, Teori \& Praktek. Jakarta : PT Raja Grafindo Persada.

Hill, H. (2001). Small and Medium Enterprise in Indonesia: Old Policy Challenges for the New Administration. Asian Survey. v.41. pp. 248-270.

Imamah Nurul, September 2008. "Peranan Business Development Service dalam Pengembangan Usaha Kecil Menengah di Wedoro Centre Waru Sidoarjo”. Jurnal Manajemen dan Kewirausahaan. Vol. 10, No.02.

James A. O’ Brien, Introduction to information System, Edition 12, 2005

Jusup, Haryono, Al. (2005). Dasar-Dasar Akuntansi. Jilid 1 dan 2. Cetakan kelima. Yogyakarta: Badan Penerbitan STIE YKPN.

Kartasapoetra. 2003. Koperasi Indonesia. Jakarta : PT Bina Adiaksara.

Kristanto, Andri. 2003. Perancangan Sistem Informasi dan Aplikasinya. Yogyakarta : GAVA MEDIA.

Kusrini dan Kinoyo, A. 2007. Tuntunan Praktis ; Membangun Sistem Informasi Akutansi dengan Visual Basic \& Microsoft SQL Server. Yogyakarta : ANDI.

Rahman, Windy Atmawardani dan Lana Sularto. 2011. Analisis dan Desain Sistem Informasi Akuntansi pada Usaha Kecil dan Menengah (Studi Kasus pada CV. Smart Teknologi Indonesia). PESAT (Psikologi, Sastra, Arsitektur dan Sipil). Vol. 4. Oktober.

Raymond McLeod, Jr, Management Information Systems, Edition 6, 1995

Tuban, McLean, Etherbe, Information Technology for Manajement, Second Edition, John Wiley \& Sons.Inc., New York, 1999. 
Jurnal IImiah Bidang Manajemen dan Akuntansi (JEMA)

Vol. 14 No. 1 (2017) - http://riset.unisma.ac.id/index.php/jema

Warsono, Sony. (2010). Akuntansi Ternyata Logis dan Mudah. Yogyakarta: Asgard Chapter.

Widiyanti dan Sunindhia. 2003. Koperasi dan Perekonomian Indonesia. Jakarta : PT Rineka Cipta.

http://id.shvoong.com/social-sciences/communication-media-studies/2236444-pengertianborland-delphi/\#ixzz2M6kpyqTn

*) Ronny Malavia M merupakan Dosen Fakultas Ekonomi Universitas Islam Malang

**) Budi Wahono merupakan Dosen Fakultas Ekonomi Universitas Islam Malang 